\title{
DIE GEMEENSKAPSWERKDIENSTE VAN DIE PRIVATE WELSYNSEKTOR: 'N PROFIEL MET IMPLIKASIES
}

\author{
AM Van den Berg \\ Krugersdorp \\ ML Weyers \\ Potchefstroom Kampus van die Noordwes Universiteit
}

\begin{abstract}
The practical implications of the significant changes in social and welfare policy that occurred from 1994 to 1999, are as yet unknown. This is mainly due to the lack of empirical research data on this issue. This deficiency was partly addressed in a study on the nature of the private welfare sector's community work services in the North West Province during 2000.

The aim of the study was to compile a profile of the Province's community work services and to utilise this profile in the formulation of guidelines for improved future service delivery.

In the study, both community work theory and the South African social and welfare policies were used in the development of a classification framework for community work services. This framework formed the basis of a questionnaire that was sent to all private welfare organisations in the Province. The collected data was analysed and, together with policy dictates, used for the development of guidelines.

It was firstly found that there was a discernable move towards targeting policy designated client systems. However, the services did still not fully comply with policy requirements or South Africa's considerable development needs. Certain deficiencies in the service delivery process were also identified. Therefore, guidelines for addressing both these imbalances and deficiencies were formulated. It was thirdly found that the new classification framework could be constructively used in both further research and in practice.
\end{abstract}

\section{INLEIDING}

Die tydperk 1994 tot 1999 is gekenmerk deur 'n aansienlike ommeswaai in Suid-Afrika se formele maatskaplike en maatskaplikewerk-beleid (Weyers, 2001:263-265). Daar is weg beweeg vanaf die vorige bedeling se beklemtoning van individu-gesentreerde terapeutiese intervensies na een waarin die vermindering van armoede en ongelykhede deur middel van ontwikkelingsgerigte maatskaplike welsyn en maatskaplike werk ("developmental social welfare/work") voorop gestel is (May, 1999:57; SA, 1999:11; Van Eeden, Ryke \& De Necker, 2000:16-17). Hiermee saam is die rol wat die burgerlike samelewing en veral die formele en informele welsynsektor in die heropbou en ontwikkeling van die land behoort te speel, ook beklemtoon (ANC, 1997; Gray, 1998:25). Hierdie beleid en beginsels het veral praktiese beslag gekry in die 1999-finansieringsbeleid vir maatskaplike welsyn (SA, 1999).

Ten spyte van die beleidsverandering en die meer as drie jaar wat sedert die publikasie van die finansieringsbeleid verloop het, is die praktiese impak daarvan nog grootliks onbekend. So byvoorbeeld is die statistiek oor Suid-Afrika se huidige gemeenskapswerk en gemeenskapsontwikkelingsdienste ooglopend onvolledig (Dept. of Social Development, 2001). Dit het ook uit die analisering van 
databasisse geblyk dat daar sedert 1999 relatief min empiriese navorsingsdata oor sodanige dienste gepubliseer is. Ten einde hierdie tekortkominge te help uitskakel, is daar gedurende 2000 'n navorsingsprojek waarin die aard van die private welsynsektor se gemeenskapswerkdienste verken is, geloods. Die resultate van hierdie ondersoek word in die hieropvolgende uiteensetting vervat.

\section{DIE ONDERSOEK}

In die ondersoek waarop hierdie uiteensetting gebaseer is, is daar op die Noordwes Provinsie gefokus. Die rede vir hierdie keuse was veral omdat die betrokke Provinsie in 'n veelheid van opsigte as 'n mikro-kosmos van die totale Suid-Afrika beskou kan word (Weyers, 1999) en die resultate gevolglik tot ' $\mathrm{n}$ redelike mate in ander provinsies veralgemeen sou kon word.

\section{Doelstellings}

In die navorsing is drie doelstellings nagestreef, naamlik:

- $\quad$ om met behulp van gemeenskapswerkteorie en die Suid-Afrikaanse welsynsbeleid, 'n klassifikasie-raamwerk vir gemeenskapswerkdienste te ontwikkel;

- $\quad$ om dié raamwerk in empiriese navorsing te gebruik om 'n profiel van die Noordwes Provinsie se gemeenskapswerkdienste op te stel; en

- $\quad$ om aan die hand van die profiel, riglyne vir die toekomstige lewering van gemeenskapswerkdienste in beide die betrokke provinsie en Suid-Afrika as geheel te formuleer.

\section{Navorsingsontwerp en -prosedure}

Die navorsing was primêr beskrywend en evaluerend van aard (Neuman, 1997:18-21) en het uit die volgende vier basiese stappe bestaan:

- Die eerste stap was om 'n posvraelys te ontwikkel wat gebruik kon word om 'n profiel van die gemeenskapswerkdienste in die Noordwes Provinsie te bepaal.

- As tweede stap is al die kantore van gemeenskapsgebaseerde welsynsorganisasies wat subsidies vanaf die Noordwes Provinsie se Departement van Maatskaplike Ontwikkeling ("Dept. of Social Development") ontvang, geïdentifiseer. In totaal was daar 26 kantore van die verskillende Kinder- en Gesinsorgverenigings, Ondersteuningsrade, die Suid-Afrikaanse Vrouefederasie (SAVF), NG Welsyn, FAMSA en Geestesgesondheid wat aan hierdie vereistes voldoen het. Pogings is ook aangewend om die Departement self by die ondersoek te betrek, maar dit was onsuksesvol. Inrigtings is, vanweë die gespesialiseerde aard van hul dienste, uit die ondersoekgroep gelaat.

- Die vraelys is daarna aan al 26 kantore gepos. In totaal het 15 kantore (57,7\%) hul vraelyste teruggestuur. 'n Bykomende drie $(11,5 \%)$ het aangetoon dat, weens die afwesigheid van die betrokke maatskaplike werkers, geen respons moontlik was nie. Geen respons kon van agt kantore $(30,8 \%)$ verkry word nie. Die relatief lae responskoers was te verwagte weens die omvangryke aard van elke vraelys en die feit dat dit per pos versprei is (Neuman, 1997:251). Tog het respons van beide groot en klein kantore, hul geografiese verspreidheid en die feit dat gedetailleerde inligting oor 48 projekte bekom is, meegebring dat die verkreë data as redelik verteenwoordigend van die aard van die betrokke tipe dienste beskou kon word. Dit is egter nie noodwendig verteenwoordigend van die omvang van dienste in die Provinsie nie. 
- As laaste stap is die ingesamelde data geanaliseer en, tesame met toepaslike teorie en beleidsvereistes, as basis vir die formulering van riglyne gebruik.

\section{Die vraelys en klassifikasie-raamwerk}

Van elke kantoor is verwag om 'n vraelys te voltooi vir elke gemeenskapswerkprojek wat vanaf 1 Januarie 2000 tot 31 Desember 2000 geïmplementeer is. Die resultate kon gebruik word om drie kategorieë van eienskappe te klassifiseer, naamlik die gemeenskapswerkproses wat gevolg is, die praktykmodelle wat benut en die beleidsvereistes wat nagekom is. Die aard en begronding van hierdie klassifikasie-raamwerk sal vervolgens kortliks in oënskou geneem word.

\section{Klassifikasie in terme van die stappe van die gemeenskapswerkproses}

Daar is na aanleiding van die sienings van onder andere Lombard (1991:247-290), Schoeman (1980:89-123) en Swanepoel (1997:70-190), besluit om die volgende vyfstap-indeling as klassifikasiekriterium te gebruik:

- $\quad$ Stap 1: Kontakmaking en die identifisering en definiëring van behoeftes en probleme. Die vrae het hier gefokus op die wyse waarop probleme en behoeftes onder die maatskaplike werker se aandag gekom het.

- $\quad$ Stap 2: Verkryging van verteenwoordiging uit die gemeenskap. Klem is geplaas op die wyse waarop en die mate waarin gemeenskapsverteenwoordiging bewerkstellig is.

- $\quad$ Stap 3: Die formulering van doelstellings en doelwitte. Die verkreë inligting kon benut word om die eindbestemming van die dienste te bepaal en in terme van hul primêre doel of fokus te klassifiseer.

- $\quad$ Stap 4: Die beplanning en implementering van dienste. Die wyse waarop praktisyns te werk gegaan het om dienste te beplan en te implementeer, is nie direk in die vraelyste gedek nie. Dit is egter só ontwerp dat die aard van die geteikende kliëntsisteme en intervensies wel bepaal sou word.

- Stap 5: Evaluering. Die wyse waarop die gemeenskapswerk-insette geëvalueer is, is pertinent in die vraelys gedek.

\section{Klassifikasie in terme van praktykmodelle}

Die vraelys het agt vrae bevat wat 'n aanduiding sou gee van die primêre praktykmodel wat in optrede benut is. Vir klassifiseringsdoeleindes is daar van 'n vyfmodel-indeling gebruik gemaak. Dit was naamlik: die gemeenskapsontwikkelingsmodel; die maatskaplike beplanningsmodel; die maatskaplike aksiemodel; die gemeenskapsopvoedingsmodel met sy gepaardgaande gemeenskapsvoorligtings- en gemeenskapskakelwerk-submodelle; en die interorganisatoriese organiseringsmodel (Popple, 1995:55-66; Rothman, 1995:28-32, 44-45; Weyers, 1991:134-146).

Die organiseringsmodel verteenwoordig in wese 'n submodel van die 'klassieke' maatskaplike beplanningsmodel. Die rede waarom dit afsonderlik hanteer is, was om vir navorsingsdoeleindes meer direk vir inter-organisatoriese samewerking en koördinering voorsiening te maak.

\section{Klassifikasie in terme van beleidsvereistes}

Daar bestaan 'n magdom staatsgegenereerde beleidsbepalings wat 'n direkte en indirekte invloed op die lewering van gemeenskapswerkdienste uitoefen. Hierdie toedrag van sake bemoeilik die identifisering van spesifieke vereistes en die bepaling van hul "relatiewe gewig". Om hierdie probleem te oorbrug, is die vyf dokumente wat as die hoekstene van die welsynsbeleid beskou kan word, eers 
geanaliseer. Dié dokumente was die Heropbou- en Ontwikkelingsprogram (HOP) (ANC, 1994), die Witskrif op Maatskaplike Welsyn (SA, 1997) en die Dept. van Maatskaplike Ontwikkeling se finansieringsbeleid (SA, 1999), Social Welfare Action Plan (SWAP) (Dept. of Welfare, 1998) en Tien-punt Plan (Dept. of Social Development, 2002:14-15). Daarna is verskeie outeurs se sienings van dié dokumente se belangrikste bepalings gebruik om 'n lys van primêre beleidsvereistes op te stel. Hierdie prosedure het die volgende agt interafhanklike vereistes opgelewer:

- Vereiste 1: Dienste moet armoede verlig en verál op die bevrediging van basiese behoeftes gerig wees (Gray, 1996:9,11; Mandela, 1994b; Naidoo, 1995:2-3; Weyers, 1997:20).

- Vereiste 2: Dienslewering moet ongelykhede rakende onder andere toegang tot dienste, hulpbronne, werksgeleenthede en die bevrediging van basiese behoeftes aanspreek (Kepe, 1999:415; May, 1999:57; Van Aardt, 1994:6-7). Die ongelykhede is verál ras-, geslags- en geografies gebaseerd (Brown \& Partab, 1999:138-140).

- Vereiste 3: Daar moet - in aansluiting by Vereiste 2 - in dienslewering op die herverspreiding van hulpbronne gefokus word (ANC, 1997; Bond, 1997:22; Naidoo, 1995:5).

- Vereiste 4: Bepaalde kwesbare groepe, persone met spesiale behoeftes en ontwikkelingsareas moet die fokus van dienslewering wees (vgl. Brown \& Partab, 1999:138-140; Coetzee \& Graaff, 1996:317; Gray, 1997:361).

- Vereiste 5: Dienste moet binne 'n multi-sektorale en 'n multi-dissiplinêre verband gelewer word (Barnard, 1989:34; Brown \& Partab, 1999:138).

- Vereiste 6: Dienslewering moet mens-gesentreerd wees en deur die mense self gedryf word (Brown \& Partab, 1999:139; Naidoo, 1995:3; Swanepoel \& De Beer, 1994:2). Dit moet verder gemeenskapsgesentreerd wees en gemeenskapsdeelname bewerkstellig (vgl. Kepe, 1999:415).

- Vereiste 7: Dienslewering moet 'n ontwikkelingsfokus hê wat verál ekonomiese groei genereer (ANC, 1997; Gray, 1996:11; Mandela, 1994a; Naidoo, 1995:2;).

- Vereiste 8: Welsynsdienste moet beskikbaar en toeganklik vir alle Suid-Afrikaners wees (Naidoo, 1995:5). Dit geld verál vir diegene met 'n beperkte inkomste en wat in afgeleë gebiede woon (SA, 1999:4, 19).

\section{'N PROFIEL VAN DIE PROSES WAT GEVOLG IS}

Daar sal vervolgens met behulp van die stappe van die gemeenskapswerkproses slegs op die mees pertinente proses-elemente van nagevorste projekte gelet word.

\section{Stap 1: Kontakmaking en die identifisering/definiëring van behoeftes/probleme}

Respondente is versoek om aan te dui hoe die probleem/behoefte onder hul aandag gekom het of wat hulle daartoe beweeg het om met die projek te begin. Hoogstens drie beweegredes kon per projek aangedui word. Dit het 'n totaal van 124 "aanmeldings" opgelewer. Dit is aan die hand van Weyers (2001:74-75) se vyf metodes vir die identifisering van stremminge geklassifiseer (sien tabel 1).

Tabel 1 toon eerstens aan dat die een of ander vorm van navorsing die grootste, enkele vorm van aanmelding was $(44,4 \%)$. Dit was egter primêr kwalitatief van aard en het hoofsaaklik bestaan uit waarnemings deur die werker $(27 / 21,8 \%)$ of uit informele persoonlik, telefonies of groepsgebonde gesprekke met gemeenskapslede $(17 / 13,7 \%)$. Kwantitatiewe navorsing soos vraelyste is slegs in 4 $(3,2 \%)$ van die projekte gebruik. 
Die tweede grootste aanmeldingskategorie was eise en versoeke (23/18,5\%). Hiervan was die grootste persentasie eise/versoeke vanaf individue of groepe binne die gemeenskap (17/13,7\%). Die relatiewe hoë voorkoms hiervan moet nie buite verband gesien word nie. Daar was tydens die ondersoek aanduidings dat werkers deur die staat, hul organisasies en die media oor bepaalde gemeenskapsprobleme/behoeftes gesensitiseer is en op hul beurt weer gemeenskapslede dienooreenkomstig beïnvloed het.

TABEL 1

WYSES WAAROP PROBLEME/BEHOEFTES "AANGEMELD" IS

\begin{tabular}{|c|c|c|c|c|}
\hline Metodes & Tipiese handelinge & $\begin{array}{c}\text { Aantal } \\
\text { pro- } \\
\text { jekte }\end{array}$ & $\begin{array}{l}\text { Persentasie }(\%) \\
\text { van alle } \\
\text { "aanmeldings" } \\
(n=124)\end{array}$ & $\begin{array}{l}\text { Persentasie }(\%) \\
\text { van handeling per } \\
\text { metode }(n=124)\end{array}$ \\
\hline $\begin{array}{l}\text { Metode 1: } \\
\text { Intervensie volg op } \\
\text { analisering van } \\
\text { bestaande dienste }\end{array}$ & $\begin{array}{l}\text { Analise van organisasie se jaar- of } \\
\text { kwartaalverslae, statistieke, en } \\
\text { bestaande dienste }\end{array}$ & 11 & $8,9 \%$ & $8,9 \%$ \\
\hline \multirow{4}{*}{$\begin{array}{l}\text { Metode 2: } \\
\text { Intervensie volg op } \\
\text { navorsing in die } \\
\text { gemeenskap }\end{array}$} & $\begin{array}{l}\text { Formele bepaling van probleem/ } \\
\text { behoefte (bv. vraelyste, ens.) }\end{array}$ & 4 & $3,2 \%$ & \multirow{4}{*}{$44,4 \%$} \\
\hline & $\begin{array}{l}\text { Waarneming van die gemeenskap deur } \\
\text { fisies in dié sisteem aanwesig te wees }\end{array}$ & 27 & $21,8 \%$ & \\
\hline & $\begin{array}{l}\text { Informele gesprekke met } \\
\text { gemeenskapslede (persoonlik, } \\
\text { telefonies of met groepe) }\end{array}$ & 17 & $13,7 \%$ & \\
\hline & $\begin{array}{l}\text { Response van gemeenskapslede op } \\
\text { werker se voorstelle }\end{array}$ & 7 & $5,7 \%$ & \\
\hline \multirow{3}{*}{$\begin{array}{l}\text { Metode 3: } \\
\text { Intervensie vorm } \\
\text { deel van die } \\
\text { organisasie se } \\
\text { dienslewering of } \\
\text { diensveld }\end{array}$} & $\begin{array}{l}\text { Die raadpleging van ander } \\
\text { professionele persone of organisasies }\end{array}$ & 10 & $8,1 \%$ & \multirow{3}{*}{$17,8 \%$} \\
\hline & $\begin{array}{l}\text { Die navolging van dienste/ projekte } \\
\text { wat deur ander organisasies gelewer } \\
\text { word }\end{array}$ & 4 & $3,2 \%$ & \\
\hline & $\begin{array}{l}\text { Die projek vorm deel van die } \\
\text { organisasie se diensveld }\end{array}$ & 8 & $6,5 \%$ & \\
\hline \multirow{2}{*}{$\begin{array}{l}\text { Metode 4: } \\
\text { Intervensie is 'n } \\
\text { reaksie op gebeure } \\
\text { of neigings }\end{array}$} & $\begin{array}{l}\text { Opspraakwekkende gebeure in die } \\
\text { gemeenskap wat veral in die media } \\
\text { weerspieël is }\end{array}$ & 6 & $4,8 \%$ & \multirow[t]{2}{*}{$10,5 \%$} \\
\hline & $\begin{array}{l}\text { In reaksie op 'n nasionale dag of } \\
\text { spesiale dag/week }\end{array}$ & 7 & $5,7 \%$ & \\
\hline \multirow{5}{*}{$\begin{array}{l}\text { Metode 5: } \\
\text { Intervensie is 'n } \\
\text { reaksie op eise of } \\
\text { versoeke }\end{array}$} & $\begin{array}{l}\text { Eise/versoeke van lede of groepe } \\
\text { binne die gemeenskap }\end{array}$ & 17 & $13,7 \%$ & \multirow{4}{*}{$18,5 \%$} \\
\hline & $\begin{array}{l}\text { In uitvoering van beleidsvereistes soos } \\
\text { deur die regering gestel }\end{array}$ & 0 & $0 \%$ & \\
\hline & $\begin{array}{l}\text { In uitvoering van die hoofkantoor/- } \\
\text { bestuur van die organisasie se beleids- } \\
\text { vereistes }\end{array}$ & 0 & $0 \%$ & \\
\hline & $\begin{array}{l}\text { In reaksie op kennisgewings/ ver- } \\
\text { soeke/riglyne/opdragte van die } \\
\text { regering, forums, 'n nasionale raad of } \\
\text { hoofkantoor }\end{array}$ & 6 & $4,8 \%$ & \\
\hline & Totale & 124 & $100 \%$ & $100 \%$ \\
\hline
\end{tabular}


Indien die voorafgaande twee tendense, tesame met die ander inhoudelikes van tabel 1 in oënskou geneem word, kan daar tot twee primêre gevolgtrekkings gekom word. Eerstens is daar van 'n redelik wye verskeidenheid van aanmeldingsmeganismes gebruik gemaak, maar het die beleidsvereistes van hetsy die staat of werkgewersorganisasie hierin bykans geen direkte rol gespeel nie. Geen redes hiervoor kon vasgepen word nie. Tweedens het die identifisering en definiëring van stremminge geneig om baie subjektief te wees en het kwantitatiewe behoeftebepalings $(4 / 3,2 \%)$ en sekondêre analise (Metode 1:11/8,9\%) slegs 'n geringe rol gespeel. Dit is aan die hand hiervan dus 'n ope vraag of al die praktykintervensies wel op sogenaamde "werklike" behoeftes gegrond was.

\section{Stap 2: Die verkryging van verteenwoordiging vanuit die gemeenskap}

In die ondersoek moes die respondente aandui of en op welke wyse gemeenskapsbetrokkenheid by projekte bewerkstellig is. Die response op hierdie vraag word in Tabel 2 vervat.

TABEL 2

WYSES WAAROP VERTEENWOORDIGING VANUIT DIE GEMEENSKAP VERKRY IS

\begin{tabular}{|l|c|c|}
\hline \multicolumn{1}{|c|}{ Metode } & $\begin{array}{c}\text { Aantal } \\
\text { projekte } \\
\text { (n=48) }\end{array}$ & $\begin{array}{c}\text { Persentasie } \\
\text { (\%) van } \\
\text { projekte }\end{array}$ \\
\hline $\begin{array}{l}\text { 'n Bestaande komitee van die teikengemeenskap is betrek tydens die } \\
\text { beplanning en implementering van die projek }\end{array}$ & 9 & 18,8 \\
\hline $\begin{array}{l}\text { 'n Nuwe komitee is vanuit die teikengemeenskap gemobiliseer en betrek } \\
\text { tydens beplanning en implementering van die projek }\end{array}$ & 9 & 18,8 \\
\hline $\begin{array}{l}\text { Dit was 'n eenmalige projek wat reeds afgehandel is en waarby daar wél } \\
\text { formele gemeenskapsverteenwoordiging betrokke was }\end{array}$ & 9 & 18,8 \\
\hline $\begin{array}{l}\text { Daar was geen formele gemeenskapsverteenwoordiging by die inisiëring, } \\
\text { beplanning, implementering en voortsetting van die projek nie }\end{array}$ & 7 & 14,6 \\
\hline $\begin{array}{l}\text { Dit was 'n eenmalige projek wat reeds afgehandel is en waarby daar geen } \\
\text { formele gemeenskapsverteenwoordiging betrokke was nie }\end{array}$ & 6 & 12,5 \\
\hline $\begin{array}{l}\text { Maatskaplike werker het self die projek geïnisieer, beplan en geïmplementeer, } \\
\text { tydens die implementeringsfase gemeenskapslede betrek wat daarna } \\
\text { toegelaat is om alleen met die projek voort te gaan }\end{array}$ & 4 & 8,3 \\
\hline $\begin{array}{l}\text { Die persone wat deur die projek bevoordeel is, is slegs tydens die } \\
\text { behoeftebepaling betrek }\end{array}$ & 1 & 2,1 \\
\hline Onbekend & 3 & 6,3 \\
\hline Totale & $\mathbf{4 8}$ & $\mathbf{1 0 0 \%}$ \\
\hline
\end{tabular}

Dit word algemeen aanvaar dat gemeenskapsbetrokkenheid 'n belangrike rol in gemeenskapswerkdienste speel deurdat dit onder andere eienaarskap en selfhelp aanwakker (vgl. Arches, 1999:53; Staples, 1999:67-68; Taylor, 1994:118-129). So 'n stap word ook in beleidsdokumente beklemtoon (vgl. Vereiste 6; SA, 1999:19). Tabel 2 toon eerstens aan dat daar in die meeste projekte (32/67\%) wel op die een of ander wyse aan hierdie verwagting voldoen is. Verteenwoordiging het veral bestaan uit komitees wat uit gemeenskapslede saamgestel is. Tweedens was daar egter in 13 projekte $(27,1 \%)$ geen gemeenskapsverteenwoordiging nie. In sewe $(14,3 \%)$ sou dit redelik onvanpas wees omdat die projekte op aspekte soos bemarking, die insameling van voedsel en die gee van erkenning aan vrywilligers betrekking gehad het. Dit het egter geblyk dat die betrekking van gemeenskapslede in die ander ses $(12,5 \%)$ projekte wel relevant sou wees. 
Daar kon tot die gevolgtrekking gekom word dat praktisyns in 'n groot mate wel aan die verwagtinge rakende gemeenskapsbetrokkenheid voldoen het. Die feit dat dit egter in $12,5 \%$ van die toepaslike gevalle nie gedoen is nie en ook dat gemeenskapslede in vier $(8,3 \%)$ projekte eers tydens die implementeringsfase betrek is, toon nog ruimte vir verbetering in hierdie verband aan.

\section{Stap 3: Die formulering van doelstellings en doelwitte}

Daar was verskeie vrae in die vraelys wat die doel en fokus van die betrokke projekte aangeraak het. Uit 'n analise van hierdie data het dit geblyk dat die 48 projekte in nege doelverwante kategorieë ingedeel kon word. Hierdie kategorieë, tesame met bykomende inligting, word in Tabel 3 opgesom.

TABEL 3

\section{DIE DOELVERWANTE KATEGORISERING VAN PROJEKTE}

\begin{tabular}{|c|c|c|c|c|}
\hline $\begin{array}{c}\begin{array}{c}\text { Kategorieë en subkategorieë van projekte in terme van } \\
\text { doelstellings/fokus }\end{array}\end{array}$ & & & $\begin{array}{l}\text { Persen- } \\
\text { tasie } \\
(\%) \text { van } \\
\text { totaal }\end{array}$ & $\begin{array}{l}\text { Aantal } \\
\text { persone } \\
\text { bereik }\end{array}$ \\
\hline Kategorie 1: Opvoedkundige projekte: & & 30 & $62,5 \%$ & 10060 \\
\hline $\begin{array}{l}\text { 1.1 Lewensvaardighede by kinders (dit het openbare opvoeding } \\
\text { tydens verskeie KBE-weke ingesluit) ( } 2 \text { projekte het jeug } \\
\text { ingesluit) }\end{array}$ & 8 & & & 6117 \\
\hline $\begin{array}{l}1.2 \text { Vaardighede met die oog op inkomste* (primêr vroue; jeug en } \\
\text { bejaardes ingesluit in } 2 \text { projekte) }\end{array}$ & 7 & & & 97 \\
\hline $\begin{array}{l}\text { 1.3 Openbare opvoeding rakende gestremdheid en } \\
\text { substansmisbruik }\end{array}$ & 5 & & & 3320 \\
\hline 1.4 Kapasiteitsuitbouing - vroue & 4 & & & 115 \\
\hline 1.5 Opvoeding rakende MIV/VIGS & 2 & & & 350 \\
\hline 1.6 Opleiding van versorgers vir bejaardes & 1 & & & 3 \\
\hline $1.7 \quad$ Entrepeneuriese vaardighede (kinders, 6-16jaar) & 1 & & & 40 \\
\hline 1.8 Misdaadvoorkomingsprogram (kinders, 6-16jaar) & 1 & & & 10 \\
\hline 1.9 Hantering van gedragsmoeilike kinders (gemik op onderwysers) & 1 & & & 8 \\
\hline Kategorie 2: Instelling van ontbrekende diens, hulpbron, fasiliteit & & 7 & $14,6 \%$ & 2221 \\
\hline 2.1 Dagsorgsentrums & 4 & & & 214 \\
\hline $\begin{array}{ll}2.2 \text { Basiese behoeftebevrediging (gesondheidsdienste - mobiele } \\
\text { kliniek) }\end{array}$ & 1 & & & 1000 \\
\hline 2.3 Naskoolsentrums & 1 & & & 7 \\
\hline 2.4 Gemeenskapsforum & 1 & & & 1000 \\
\hline $\begin{array}{l}\text { Kategorie 3: Basiese behoeftebevrediging: Voedsel (vir gesinne- } \\
\text { kliëntelading) }\end{array}$ & & 3 & $6,3 \%$ & 250 \\
\hline Kategorie 4: Vrywilligers & & 2 & $4,2 \%$ & 119 \\
\hline 4.1 Erkenning & 1 & & & 26 \\
\hline 4.2 Ondersteuningsnetwerk vir pleeggesinne & 1 & & & 93 \\
\hline Kategorie 5: Werkskepping (slegs vroue) & & 2 & $4,2 \%$ & 8 \\
\hline Kategorie 6: Bemarking van organisasie & & 1 & $2,1 \%$ & Onbekend \\
\hline Kategorie 7: Bemarking van bestaande hulpbron (aan gesinne) & & 1 & $2,1 \%$ & 50 \\
\hline Kategorie 8: Fondsinsameling & & 1 & $2,1 \%$ & N.v.t. \\
\hline Kategorie 9: Kerspartytjie & & 1 & $2,1 \%$ & 20 \\
\hline Totale & & 48 & $100 \%$ & - \\
\hline
\end{tabular}

* Sommige van hierdie projekte is deur respondente as "werkskepping" getipeer omdat dit sporadies wel 'n minimale inkomste vir projeklede genereer. Vir die doeleindes van die ondersoek is egter slegs projekte wat 'n meer deurlopende inkomste vir deelnemers verseker, as "werkskepping" geklassifiseer. 
Tabel 3 toon eerstens aan dat 'n beduidende meerderheid van projekte $(30 / 62,5 \%)$ opvoedkundig van aard was en gemiddeld 335 persone bereik het. Dit word gevolg deur projekte gerig op die instelling van 'n ontbrekende diens, hulpbron of fasiliteit (7/14.6\%) met gemiddeld 317 persone per projek. Die ander $11(22,9 \%)$ projekte het sewe verskillende kategorieë beslaan en kan gevolglik as redelik ad hoc van aard beskou word.

Die hoë voorkoms van opvoedingsprojekte kon nie bloot aan gemeenskapsbehoeftes toegeskryf word nie. Dié tipe intervensie se vermoë om groot getalle mense te betrek, gekoppel aan die rol wat kwantitatiewe uitkomste in staatsubsidies speel (vgl. Dept. of Welfare, 1998:iii-iv), kon moontlik ook praktisyns se voorkeure beïnvloed het.

Die inhoud van en die data waarop Tabel 3 gegrond is, het tweedens aangedui dat daar waarskynlik onsekerheid by die betrokke maatskaplike werkers oor die wesentlike aard van gemeenskapswerkdienste bestaan. Feitlik enige tipe intervensie wat nie statutêr of terapeuties op kliënte afgestem is nie, is as gemeenskapswerk geklassifiseer. Vandaar hul tipering van onder andere 'n kerspartytjie vir arm kinders en gevallewerk-ondersteunende aksies (bv. blikkiekos-insamelings) as hetsy gemeenskapswerk of gemeenskapsontwikkeling. Die onsekerheid kon egter te wagte gewees het in die lig daarvan dat daar in die literatuur en beleidsdokumente verwarrende boodskappe in hierdie verband oorgedra word (vgl. Weyers, 1997:11,22).

Derdens is direkte werkskepping in slegs twee $(4,2 \%)$ projekte as primêre doel gestel en het dit net agt persone betrek (Tabel 3). Hierdie tendens strook nie met beleidsvereistes nie. Tog moet dit gesien word teen die agtergrond daarvan dat indirekte vorme van ekonomiese bemagtiging wel in $8(16,7 \%)$ van die ander projekte plaasgevind het (Tabel 3: 1.2, 1.8). Die betrokke terrein is derhalwe nie so afgeskeep as wat dit met die eerste oogopslag mag blyk nie.

Uit bykomende data wat ingewin is, het dit vierdens geblyk dat slegs $15(31,3 \%)$ van die projekte van 'n deurlopende aard (dus 365 dae of langer) was en dat die ander projekte gemiddeld 149 dae geduur het. Hierdie data versterk die indruk dat dienste op grondvlak geneig het om redelik ad hoc van aard te wees.

Daar kan aan die hand van die voorafgaande tot die slotsom gekom word dat dienste tydens die betrokke tydperk oorwegend opvoedkundig en ad hoc van aard was. Dit het meegebring dat die beleidsvereistes van armoedeverligting (Vereiste 1) en die generering van ekonomiese groei (Vereiste 7) nie werklik nagekom is nie.

\section{Stappe 4 \& 5: Die beplanning en implementering van dienste, en evaluering}

Die belangrikste inhoudelikes van die betrokke projekte se beplanning en implementering word indirek in die hieropvolgende diensleweringsprofiele vervat. Dit is egter nodig om hiér spesifiek op die evalueringsfaset te let.

Die vraelys het drie vrae wat die evaluering van projekte aangeraak het, bevat. Respondente moes aandui of evaluering plaasgevind het en indien wel, watter vorm dit aangeneem het. Waar dit nie gedoen is nie, moes die rede(s) vir die betrokke toedrag van sake verstrek word.

Daar is bevind dat in $11(22,9 \%)$ van die projekte geen evaluering plaasgevind het nie. In vyf $(10,4 \%)$ van dié gevalle is geen redes hiervoor verstrek nie en in drie $(6,3 \%)$ is "slegs supervisie met supervisor vind plaas" as rede aangevoer. Nog drie redes was die feit dat "die projek in die beginfase is en evaluering later sal plaasvind", dit nog nie "volgens staatsvereistes geregistreer" is nie en "die projek loop nog". Die laaste drie strook nie met die beginsel dat evaluering 'n deurlopende proses is wat selfs in die beplanningsfase moet geskied nie (Swanepoel, 1997:175). 
Waar evaluering wel plaasgevind het, het dit meestal uit projeklede se mondelinge terugvoer bestaan (23/47,9\% projekte). Dit is soms gekombineer met die mate van deelname aan en die bywoning van projekte $(13 / 27 \%)$ as evalueringskriterium. In slegs $11(22,9 \%)$ projekte is daar van die een of ander vorm van geskrewe terugvoer (bv. vraelyste) gebruik gemaak.

Die voorafgaande tendense dui daarop dat evaluering òf glad nie òf oorwegend op 'n informele wyse geskied het. Dit het die indruk geskep dat praktisyns evaluering as 'n 'opsionele ekstra' (Francis \& Henderson, 1992:124) beskou.

\section{'N PROFIEL VAN DIE PRAKTYKMODELLE WAT GEBRUIK IS}

Ten einde verwarring en waninterpretasie te voorkom, is daar in die vraelys nie direk na praktykmodelle verwys nie. Die sleutelhandelinge van elke model is egter gespesifiseer en daar is van respondente verwag om aan te toon (a) in watter mate hierdie handelinge in elke projek uitgevoer is en (b) wat hul relatiewe belangrikheid was. Hieruit kon daar bepaal word watter modelle as die primêre en as die sekondêre uitgangspunte in optrede benut is. Die response word in Tabel 4 vervat.

TABEL 4

DIE PRAKTYKMODELLE WAT IN DIE PROJEKTE GEBRUIK IS

\begin{tabular}{|c|c|c|c|}
\hline Die model en gepaardgaande kernhandelinge & $\begin{array}{c}\text { Primêre } \\
\text { model } \\
(\mathrm{N}=47)^{*}\end{array}$ & $\begin{array}{l}\text { Sekondêre } \\
\text { model } \\
(\mathrm{N}=36)\end{array}$ & $\begin{array}{l}\text { Algemene } \\
\text { voorkoms } \\
(\mathrm{N}=\mathbf{8 3})\end{array}$ \\
\hline $\begin{array}{l}\text { Die gemeenskapsontwikkelingsmodel: } \\
\text { Handelinge is gerig om selfhelp by 'n gemeenskapsgroep(e) te } \\
\text { bewerkstellig. }\end{array}$ & $\begin{array}{c}6 \\
12,8 \%\end{array}$ & $\begin{array}{c}11 \\
30,6 \%\end{array}$ & $\begin{array}{c}17 \\
20,5 \%\end{array}$ \\
\hline $\begin{array}{l}\text { Die maatskaplike beplanningsmodel: } \\
\text { Handelinge is daarop gerig om (a) 'n nuwe diens/ hulpbron in } \\
\text { te stel en/of (b) die kwaliteit/omvang van bestaande } \\
\text { dienste/hulpbronne te verbeter. }\end{array}$ & $\begin{array}{c}5 \\
10,6 \%\end{array}$ & $\begin{array}{c}8 \\
22,2 \%\end{array}$ & $\begin{array}{c}13 \\
15,7 \%\end{array}$ \\
\hline $\begin{array}{l}\text { Die maatskaplike aksiemodel: } \\
\text { Handelinge is daarop gerig om onregverdige optrede of } \\
\text { diskriminasie teen 'n benadeelde gemeenskapsgroep uit die } \\
\text { weg te ruim. }\end{array}$ & $\begin{array}{c}1 \\
2,1 \%\end{array}$ & $\begin{array}{c}1 \\
2,8 \%\end{array}$ & $\begin{array}{c}2 \\
2,4 \%\end{array}$ \\
\hline $\begin{array}{l}\text { Die gemeenskapsopvoedingsmodel: Voorligting: } \\
\text { Handelinge is daarop gerig om gemeenskapslede op een of } \\
\text { ander wyse op te voed of met vaardighede toe te rus. }\end{array}$ & $\begin{array}{c}31 \\
66,0 \%\end{array}$ & $\begin{array}{c}5 \\
13,9 \%\end{array}$ & $\begin{array}{c}36 \\
43,4 \%\end{array}$ \\
\hline $\begin{array}{l}\text { Die gemeenskapsopvoedingsmodel: Skakelwerk: } \\
\text { Handelinge is daarop gerig om die beeld van u organisasie } \\
\text { en/of van die maatskaplikewerk-professie uit te bou of om u } \\
\text { organisasie se dienste te bemark. }\end{array}$ & $\begin{array}{c}3 \\
6,4 \%\end{array}$ & $\begin{array}{c}5 \\
13,9 \%\end{array}$ & $\begin{array}{c}8 \\
9,6 \%\end{array}$ \\
\hline $\begin{array}{l}\text { Die organiseringsmodel: } \\
\text { Handelinge is daarop gerig om die dienste van verskillende } \\
\text { welsyns- en of diensorganisasies beter te koördineer. }\end{array}$ & $\begin{array}{c}0 \\
0 \%\end{array}$ & $\begin{array}{c}5 \\
13,9 \%\end{array}$ & $\begin{array}{c}5 \\
6,0 \%\end{array}$ \\
\hline Onbepaalbaar (" ${ }^{* *}$ "Kersboom" en ${ }^{* * * *}$ "Voeding") & $1^{* *} / 2,1 \%$ & $1^{* * * *} / 2,8 \%$ & $2 / 2,4 \%$ \\
\hline Totale & $47 / 100 \%$ & $36 / 100 \%$ & $83 / 100 \%$ \\
\hline
\end{tabular}

* Een projek se response kon nie benut word nie. 
Uit Tabel 4 blyk dit dat die voorligtingsubmodel van gemeenskapsopvoeding met 'n totaal van 43,4\%, beduidend meer as enige van die ander modelle aangewend is. Die meeste projekte $(66,0 \%)$ het dit ook as primêre uitgangspunt benut en dit is slegs in 'n beperkte mate as sekondêre metode in ander projekte benut.

Gemeenskapsontwikkeling was die naas mees benutte model, maar is tog net in 20,5\% van die projekte gebruik. Dit het veral 'n sekondêre rol vertolk (30,6\%) en is dus gewoonlik ondergeskik tot ander modelle aangewend. Hierdie tendense moet gesien word in die lig daarvan dat die betrokke model die meeste raakpunte met bestaande beleidsprioriteite het (Weyers, 1997:51-129).

Die ander vier modelle is in ' $\mathrm{n}$ beduidend geringer mate in projekte benut. Veral opvallend was die feit dat die bevordering van interorganisatoriese koördinering in net $5(6 \%)$ van die projekte 'n sekondêre rol gespeel het. Hierdie tendens ontken nie net die waarde wat die model vir die uitskakeling van duplisering en gebrekkige hulpbronne inhou nie (Popple, 1995:59-60), maar ook die beleidsvereiste van multi-sektorale dienslewering.

Die voorafgaande tendense dui op 'n mate van teenstrydigheid tussen die primêre fokus van beleidsdokumente en die grondvlak-implementering van gemeenskapswerkdienste. Die dienste was oorwegend voorligtingsgesentreerd, terwyl die verbetering van dienste/hulpbronne en die bevordering van selfhelp grootliks 'n sekondêre rol gespeel het. Dit ten spyte daarvan dat veral laasgenoemde die primêre fokus van beleidsdokumente is. Die slotsom waartoe gekom kan word, is dat daar 'n wanbalans in die betrokke provinsie en waarskynlik Suid-Afrika se gemeenskapswerkdienste bestaan.

\section{'N PROFIEL VAN DIE BELEIDSVEREISTES WAARAAN VOLDOEN IS}

In die daarstelling van 'n beleidsverwante profiel van die gelewerde dienste is daar op vyf aspekte gelet. Dit is onderskeidelik die terreine van dienslewering wat betree is, die graad van multi-sektorale samewerking, die kenmerke van die kliëntsisteme, die ontwikkelingsareas wat geteiken is en die geografiese verspreiding van projekte.

\section{Die terreine van dienslewering wat betree is}

Een van die beginsels onderliggend aan ontwikkelingsgerigte maatskaplike welsyn en -werk is dat maatskaplike werkers buite die eng welsynsterrein moet beweeg om ook op die breë maatskaplike- en gemeenskapsontwikkelingsterrein 'n bydrae te lewer (Midgley, 1995:1; SA, 1997:5). Om te kon bepaal in watter mate dienste aan hierdie beginsel voldoen het, is Weyers (1997:11-12) se indeling van die werksterrein van gemeenskapswerk en -ontwikkeling as analiseringsraamwerk gebruik. Die resultate word in Diagram 1 vervat. 


\section{DIAGRAM 1 \\ DIE TERREINE WAT IN DIENSLEWERING BETREE IS}

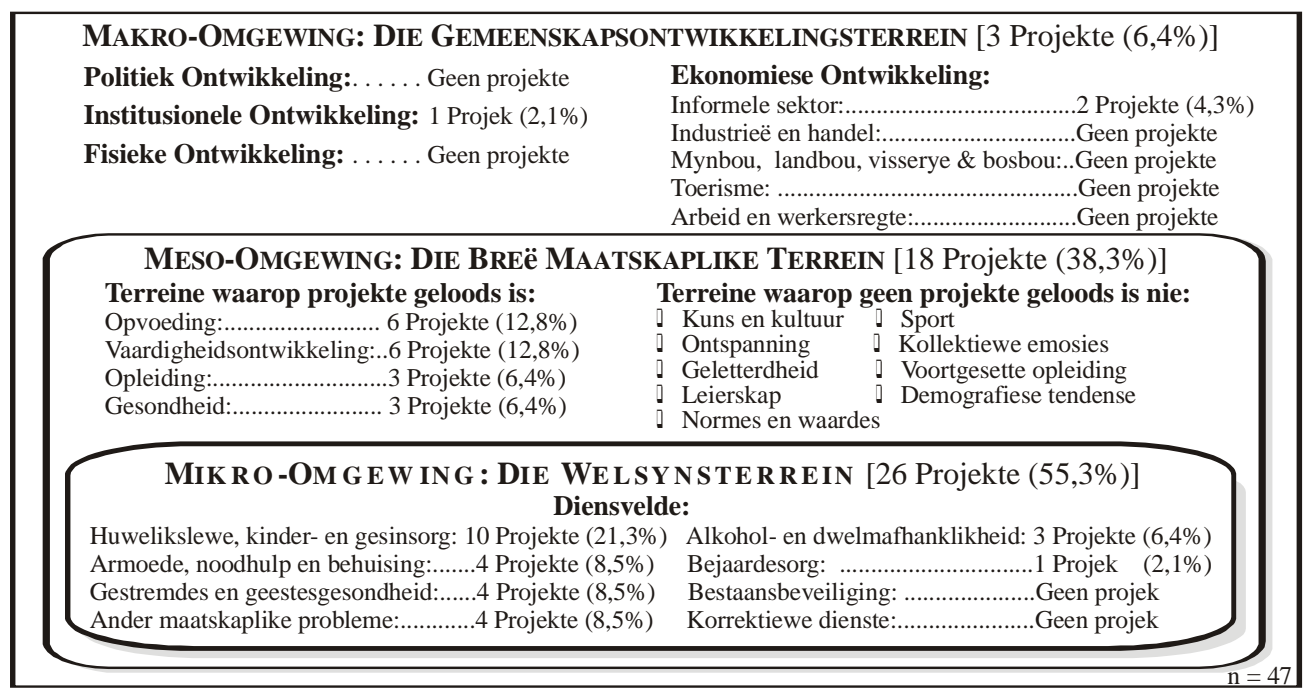

Nota: Een projek was op fondsinsameling gemik en is gevolglik nie in berekening gebring nie.

Soos deur Diagram 1 aangetoon, het die meeste projekte - te wete $26(55,3 \%)$ - op die sogenaamde welsynsterrein geval. 'n Redelik wye verskeidenheid van diensvelde is hierdeur aangeraak, maar by $10(21,3 \%)$ projekte is daar hierin veral op die huwelikslewe, kinder- en gesinsorg gefokus.

Van die $18(38,3 \%)$ projekte wat op die breë maatskaplike terrein geloods is, was die meeste $(15 / 31,3 \%)$ onderrigverwant en die res $(3 / 6,4 \%)$ gesondheidsverwant. Nege van die maatskaplike terrein se ander "diensvelde" is nie aangespreek nie.

Slegs drie $(6,4 \%)$ van die 48 projekte het op die breë gemeenskapsontwikkelingterrein geval. Hiervan het twee $(4,3 \%)$ op informele ekonomiese ontwikkeling gefokus en die derde op institusionele ontwikkeling.

Uit die voorafgaande kan daar eerstens tot die gevolgtrekking gekom word dat maatskaplike werkers, in teenstelling met beleidsdenkrigtings, slegs in 'n beperkte mate buite die eng welsynsterrein beweeg het en dat hulle veral nie op die makro-gemeenskapsontwikkelingsterrein bedrywig was nie. Tweedens was dit opvallend dat werkers in ten minste nege $(19,2 \%)$ projekte self die rol van byvoorbeeld onderwyser en gesondheidswerker vertolk het. Hieruit kan afgelei word dat hulle neig om eerder bepaalde verantwoordelikhede self te dra as om van die professionele insette van verteenwoordigers uit ander sektore gebruik te maak.

\section{Die graad van multi-sektorale samewerking}

In beleidsdokumente word daar 'n hoë premie op multi-sektorale samewerking geplaas. Daarom is hierdie aspek pertinent in die vraelys gedek. Die resultate word in Tabel 5 opgesom. 
TABEL 5

'N PROFIEL VAN INSTANSIES WAT BY PROJEKTE BETREK IS

\begin{tabular}{|c|c|c|c|c|}
\hline \multirow[b]{2}{*}{ Tipe instellings betrek } & \multicolumn{4}{|c|}{ Aantal instellings $(\mathrm{N}=71)$} \\
\hline & $\begin{array}{c}\text { Sub- } \\
\text { kategorie }\end{array}$ & $\begin{array}{l}\% \text { van } \\
\text { totaal }\end{array}$ & Kategorie & $\begin{array}{l}\text { \% van } \\
\text { totaal }\end{array}$ \\
\hline \multicolumn{3}{|l|}{ Die owerheidsektor: } & \multirow{8}{*}{22} & \multirow{8}{*}{$31 \%$} \\
\hline - $\quad$ Departement Maatskaplike Ontwikkeling & 5 & $7 \%$ & & \\
\hline - $\quad$ Departement Onderwys & 2 & $2,8 \%$ & & \\
\hline - $\quad$ Departement Gesondheid & 4 & $5,6 \%$ & & \\
\hline - $\quad$ Departement Landbou & 1 & $1,4 \%$ & & \\
\hline - $\quad$ SAPD, Korrektiewe Dienste en landdroskantore & 8 & $11,3 \%$ & & \\
\hline - $\quad$ Munisipaliteit & 1 & $1,4 \%$ & & \\
\hline - $\quad$ Staatsbefondsingsprogramme & 1 & $1,4 \%$ & & \\
\hline \multicolumn{3}{|c|}{$\begin{array}{l}\text { Gemeenskapgroepe (bv. kerkgroepe, VLU, gemeenskapsgebaseerde groepe, } \\
\text { vrywilligers) }\end{array}$} & 14 & $19,7 \%$ \\
\hline \multicolumn{3}{|l|}{ Opleidingsinstellings: } & \multirow{5}{*}{13} & \multirow{5}{*}{$18,3 \%$} \\
\hline - $\quad$ Kleuterskole & 1 & $1,4 \%$ & & \\
\hline - $\quad$ Primêre en sekondêre skole & 10 & $14,1 \%$ & & \\
\hline - $\quad$ Tersiêr & 1 & $1,4 \%$ & & \\
\hline - $\quad$ Ander & 1 & $1,4 \%$ & & \\
\hline \multicolumn{3}{|l|}{ Besighede } & 11 & $15,5 \%$ \\
\hline \multicolumn{3}{|c|}{$\begin{array}{l}\text { Welsynsinstellings (o.a. NPO's in die gesin- en bejaardesorgvelde, asook } \\
\text { spesialiteitsinrigtings soos kinderhuise en dienssentrums) }\end{array}$} & 8 & $11,3 \%$ \\
\hline \multicolumn{3}{|l|}{ Die media (veral koerante en radiostasies) } & 3 & $4,2 \%$ \\
\hline \multicolumn{3}{|c|}{ Totaal betrek } & 71 & $100 \%$ \\
\hline \multicolumn{3}{|c|}{ Geen ander instansies betrek nie } & 7 & \\
\hline
\end{tabular}

Uit Tabel 5 is dit duidelik dat samewerking hoofsaaklik met owerheidsinstellings (22 projekte) plaasgevind het, gevolg deur gemeenskapsgroepe (14 projekte) en opleidingsinstellings (13 projekte). Besighede is by 11 projekte betrek, terwyl daar in agt projekte met ander welsynsinstansies saamgewerk is.

Die eerste faktor wat in Tabel 5 opval is dat geen ander instellings by $7(14,6 \%)$ van die projekte betrek is nie, terwyl daar in die orige 41 projekte met 71 ander instellings (dus gemiddeld 1,7 instellings per projek) saamgewerk is. 'n Tweede tendens was dat daar groter samewerking met die ander welsynsinstansies (8 projekte) as met die Departement van Maatskaplike Ontwikkeling (5 projekte) en met opleidingsinstellings (13 projekte) as met die Departement van Onderwys (2 projekte) plaasgevind het. Dit dui moontlik op gebreke in die samewerking tussen die owerheidsektor en die betrokke welsynsorganisasies. 
Uit al die data kan daar tot die gevolgtrekking gekom word dat die praktisyns wel oor die vermoë beskik om met instansies in beide die openbare en private sektor saam te werk. Die aard en omvang daarvan was redelik in lyn met die oorwegend opvoedkundige aard van die gelewerde dienste in die maatskaplike sektor, maar het nie heeltemal aan die beleidsvereistes van multi-sektorale en multidissiplinêre samewerking en ontwikkelingsgerigte dienslewering (sien vereistes 5 \& 6) voldoen nie.

Uit al die data kan daar tot die gevolgtrekking gekom word dat die praktisyns wel oor die vermoë beskik om met instansies in beide die openbare en private sektor saam te werk. Die aard en omvang daarvan was redelik in lyn met die oorwegend opvoedkundige aard van die gelewerde dienste, maar het in geheel gesien, nie heeltemal aan die gestelde beleidsvereistes voldoen nie.

\section{Die kenmerke van die geteikende kliëntsisteme}

In die ondersoek is bestaande beleidsvereistes gebruik om potensiële kliëntsisteme oorhoofs op grond van hul ras, kwesbaarheid, posisie binne ontwikkelingsareas en ekonomiese posisie te kategoriseer. Die verkreë data sal vervolgens aan die hand van hierdie kenmerke bespreek word.

DIAGRAM 2

DIE RASSEVERSPREIDING VAN GETEIKENDE KLIËNTSISTEME IN VERGELYKING MET DIE RASSEVERSPREIDING VAN DIE RSA EN NOORDWES PROVINSIE

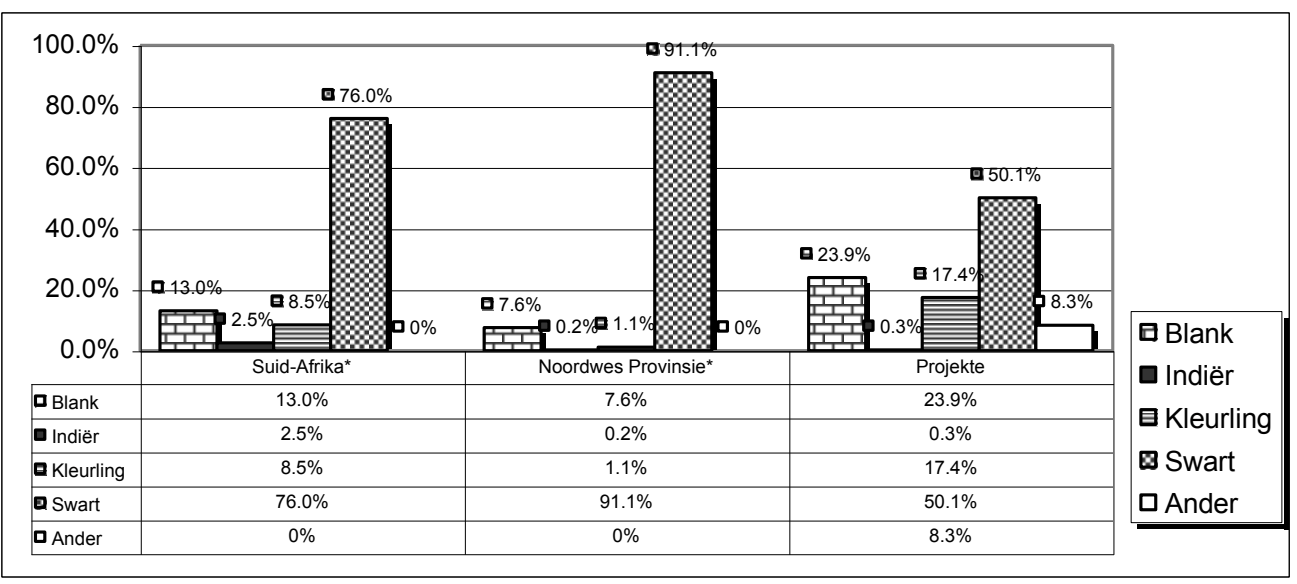

*Bron: "Development Bank of Southern Africa" (SAIR, 1995:5).

\section{Die rasseverspreiding van die geteikende kliëntsisteme}

Daar is van respondente verwag om persentasiegewys die rasseverspreiding per projek aan te dui. In Diagram 2 word hierdie verspreiding, tesame met die rasseverspreiding in Suid-Afrika en die Noordwes Provinsie, opgesom. Die kategorie "Onbepaalbaar" verwys hierin veral na ontvangers waarvan die rasseverspreiding nie met sekerheid vasgestel kon word nie, soos byvoorbeeld in die geval van koerantberigte en uitstallings in winkelsentrums.

Uit die data (sien Diagram 2) het dit geblyk dat meer as die helfte van die geteikende kliëntsisteme $(50,1 \%)$ uit die swart bevolking bestaan het, terwyl blankes $23,9 \%$ en kleurlinge $17,4 \%$ daarvan uitgemaak het. Wanneer hierdie verspreiding met die rasseverspreiding van Suid-Afrika en veral die 
Noordwes Provinsie vergelyk word, blyk dit dat die swart bevolking steeds onderverteenwoordig in dienslewering was. As dit egter in ag geneem word dat die sogenaamde nie-blanke bevolking voor 1994 slegs in 'n uiters beperkte mate deur die private welsynsektor bedien is, dui die huidige data tog daarop dat hul gemeenskapswerkdienste transformasie ondergaan het. Daar bestaan egter nog ruimte vir verdere transformasie.

\section{Die kwesbare groepe wat bereik is}

Daar is na aanleiding van 'n indiepte analise van beleidsdokumente (vgl. Van den Berg, 2002: 41-3) tot die gevolgtrekking gekom dat daar veral ses sogenaamde kwesbare groepe, oftewel "vulnerable groups" (SA, 2001:501) of "focus groups" (SA, 1999:14) in beleid gespesifiseer word. Dit is onderskeidelik kinders van 0-6 jaar, kinders van 6-16 jaar, die jeug (16-30 jaar), gesinne, vroue en bejaardes. Hierdie groepe is onder andere in die vraelys gespesifiseer en daar is van respondente verwag om persentasiegewys aan te dui in welke mate hierdie groepe in hul dienslewering bereik is. Die respondente kon bykomend ook kliëntsisteme spesifiseer wat nie deel van die kwesbare groepe vorm nie. Die verkreë data word in Diagram 3 weergegee.

\section{DIAGRAM 3 \\ DIE VERSPREIDING VAN GETEIKENDE KLIËNTSISTEME IN TERME VAN KWESBARE GROEPE}

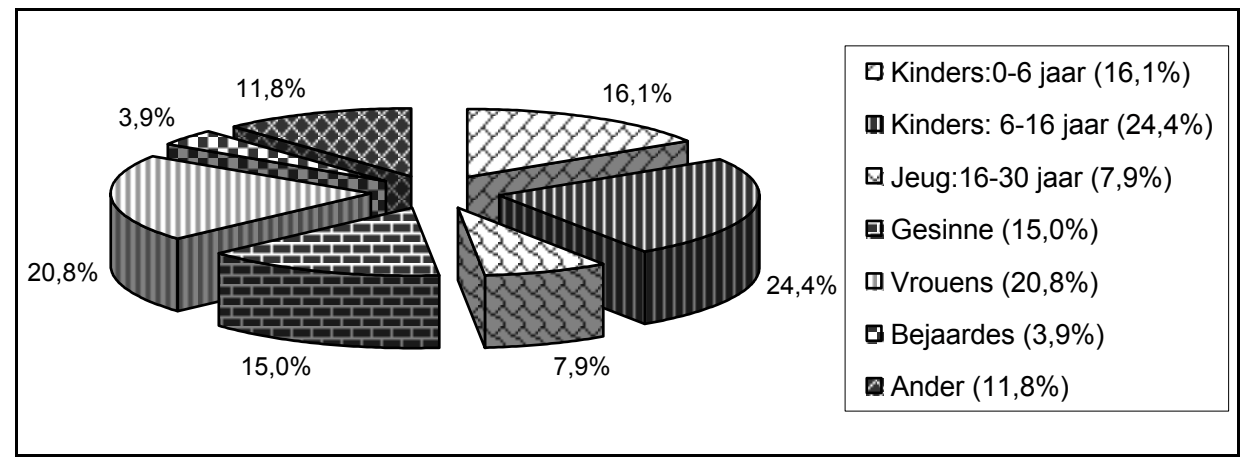

Uit Diagram 3 is dit duidelik dat $88,2 \%$ van al die gemeenskapswerkprojekte se kliëntsisteme uit kwesbare groepe bestaan het. Die ander 11,8\% was hoofsaaklik onderwysers en ander professionele persone, die breë publiek (die teiken van bemarkings- en bewusmakingsprojekte), vrywilligers en mans. Van die kwesbare groepe het kinders tussen 6-16 jaar $(24,4 \%)$, vroue $(20,8 \%)$ en kinders tussen $0-6$ jaar $(16,1 \%)$ die meeste aandag ontvang.

Kinders in die ouderdomsgroep 0-6 jaar word as besonder kwesbaar beskou en ongeveer $60 \%$ leef in verarmde toestande (vgl. SA, 1997:39-52). Tog het dit opgeval dat kinders in die ouderdomsgroep 616 jaar met $24,4 \%$ beduidend meer aandag as $0-6$ jariges $(16,1 \%)$ ontvang het.

Ten spyte daarvan dat Suid-Afrika se jeug aansienlike sosio-ekonomiese probleme in die gesig moet staar (vgl. SA, 1997:47-8; Van Aardt, 1994:25-6, 52), het dié groep slegs 7,9\% van die totale kliëntsisteem uitgemaak. Die betrokke dienste was ook slegs opvoedkundig van aard en veral gemik op die ontwikkeling van hul inkomstegenereringsvaardighede (25 jeugdiges), lewensvaardighede en opvoeding rakende MIV/VIGS en geestesgesondheid.

Volgens die Witskrif (SA, 1997:50) moet dienslewering aan bejaardes veral fokus op die verbetering van hul toegang tot gesondheidsdienste en voedingsprogramme, asook integrasie in die gemeenskap. 
Die dienste wat gelewer is, was wel gemik op die opleiding van versorgers en die instelling van 'n mobiele kliniek wat die hele gemeenskap (insluitend bejaardes) bedien, asook op hul opleiding in inkomstegenereringsvaardighede (sien Tabel 3). Bejaardes het egter die kleinste persentasie $(3,9 \%)$ van die globale kliëntsisteem uitgemaak.

Vroue is die slagoffers van armoede, diskriminasie, misbruik en geweld (May, 1999:55) en volgens beleid moet dienslewering 'n bydra lewer tot die bewerkstelliging van gelykheid tussen mans en vroue in alle sfere van die sosiale, ekonomiese en burgerlike lewe (SA, 1997:52). In die ondersoek het vroue met $20,8 \%$ 'n relatief hoë proporsie van geteikende kliëntsisteme uitgemaak. Die betrokke dienste was primêr gerig op ekonomiese bemagtiging, die uitbouing van hul kapasiteite, opvoeding rakende MIV/VIGS en toegang tot 'n mobiele kliniek (sien Tabel 3). Die enigste terrein wat nie werklik gedek is nie, was die misbruik van en geweld teen vroue.

In die ondersoek het gesinne per se 15\% van die kliëntsisteem uitgemaak. Dienslewering het gefokus op die voorsiening van voedsel, kapasiteitsbouprojekte, opvoeding rakende MIV/VIGS en substansmisbruik. Lewensvaardighede, huweliksvoorbereiding en die hantering van gesinsgeweld is nie aangeraak nie en die uitbouing van ouerskapsvaardighede het net beperkte aandag geniet.

In die geheel gesien kan daar tot die gevolgtrekking gekom word dat daar 'n redelik goeie balans was tussen die verskillende kwesbare groepe wat geteiken is. Daar is egter aanduidings dat kinders tussen 6-16 jaar oorverteenwoordig was, terwyl die jeug en bejaardes nie genoegsame aandag gekry het nie. Die sterk opvoedkundige aard van die dienste het meegebring dat kontensieuse aangeleenthede soos gesinsgeweld en die misbruik van vroue, asook bestaansbeveiligingsmaatreëls soos voedingsprogramme, nie genoegsame aandag ontvang het nie.

\section{Die ontwikkelingsareas wat geteiken is}

Daar is van respondente verwag om aan te dui watter van die beleidsgeïdentifiseerde ontwikkelingsareas deur die projekte aangespreek is. Die ontwikkelingsareas wat met behulp van 'n analise van beleid geïdentifiseer is, was armoede, misdaad, substansmisbruik, gestremdes (fisies en geestelik) en chroniese siektes (MIV/VIGS en ander) (vgl. SA, 1997:53-66). Respondente kon ook ander areas byvoeg. Die inligting wat in hierdie verband ingewin is, word in Diagram 4 opgesom.

\section{DIAGRAM 4 \\ DIE VERSPREIDING VAN GETEIKENDE KLIËNTSISTEME IN TERME VAN ONTWIKKELINGSAREAS}

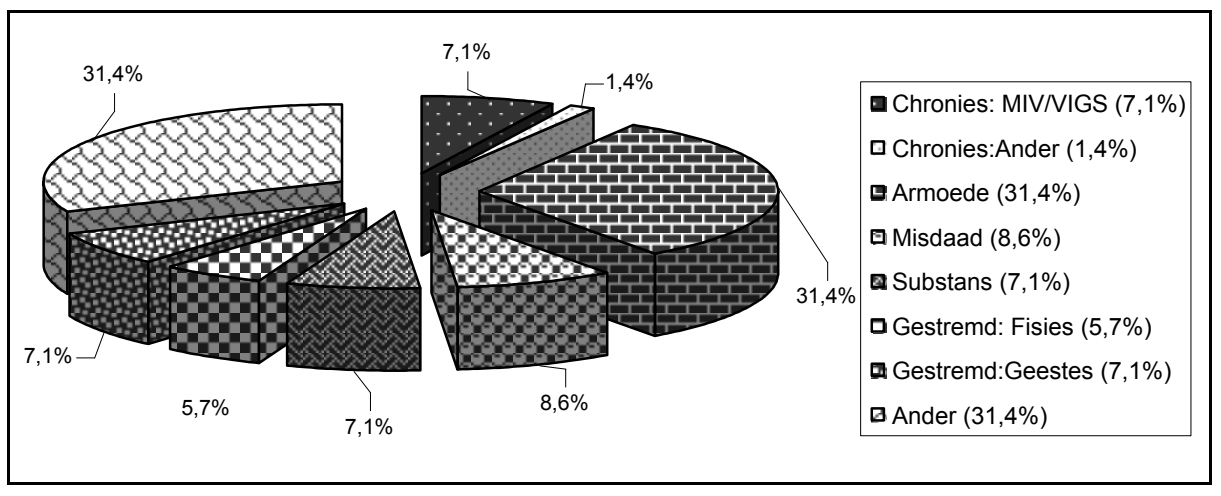


Dit is opvallend uit die response dat bykans 'n derde (31,4\%) betrekking gehad het op areas wat respondente tot die bestaandes bygevoeg het (sien Diagram 4). Dit het aspekte ingesluit soos vrouebemagtiging, gebrekkige lewenskwaliteit, persoonsontwikkeling (bv. die ontwikkeling van selfkennis en selfhandhawende gedrag); erkenning aan die vrywilligerskorps; creché-verwante aktiwiteite (bv. die opleiding van versorgers), die funksionering van 'n naskoolsentrum, die "wonder van Kersfees" en statutêre dienste. Hierdie tendens is waarskynlik die gevolg van die heersende persepsie dat bykans alles wat nie terapeutiese of statutêre dienste is nie, as gemeenskapswerk geklassifiseer kan word. Dit is egter ook ' $n$ indikator van die diversiteit van dienste waarby praktisyns betrokke is.

Naas "ander", was armoede met $31,4 \%$ die primêre fokus van dienslewering. Die ontwikkelingsareas van misdaad, substansmisbruik, MIV/VIGS, geestesgesondheid en fisiese gestremdheid het relatief ewe veel aandag geniet, terwyl "ander chroniese siektes" in net een $(1,4 \%)$ projek geteiken is.

Uit Diagram 4 en die data waarop dit gebaseer is, kon daar tot die gevolgtrekking gekom word dat 'n groot verskeidenheid ontwikkelingsareas geteiken is. In die betrokke dienste is daar via voorligting veral op primêre voorkoming gefokus. Hierteenoor is verskeie ontwikkelingsareas soos fisies- en geestesgestremde persone, oortreders en substansafhanklikes nie direk bereik nie. Die armoedevraagstukke is oorwegend op 'n indirekte wyse aangespreek en dus is daar nie ten volle aan beleidsvereistes 1 tot 3 gehoor gegee nie.

\section{Die ekonomiese posisie van kliëntsisteme}

In die analise van die kenmerke van kliëntsisteme is daar vierdens op hul ekonomiese posisie gelet. Die rede hiervoor was om te bepaal in watter mate die dienste voldoen het aan die anti-armoede fokus wat deur beleidsdokumente vereis word.

Die inkomsteverspreiding van die kliëntsisteme is in vyf generiese en drie bykomende kategorieë verdeel. Laasgenoemde het bestaan uit "arm gemengd" ('n kombinasie van "armste van armes", "baie arm" en "arm: lae inkomstegroep"), "onbepaalbaar" (vir projekte waarvan die ekonomiese posisie van teikengroepe - soos bv. skougangers - nie vasgestel kon word nie) en "nie van belang" (soos bv. in die geval van die verlening van erkenning aan vrywilligers). Dit is van respondente verwag om slegs een kenmerk uit hierdie kategorieë per projek te merk. Die resultate word in Diagram 5 vervat.

\section{DIAGRAM 5
DIE INKOMSTEVERSPREIDING VAN GETEIKENDE KLIËNTSISTEME}

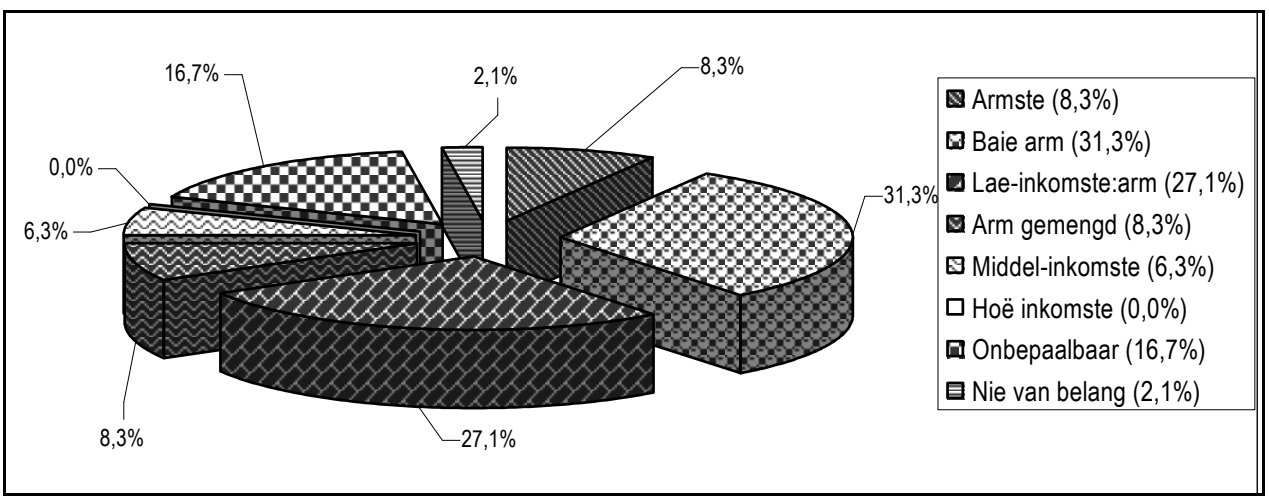


Dit blyk uit Diagram 5 dat 75\% van die gemeenskapswerkdienste op die arm deel van die bevolking toegespits was, met "baie arm" (31,3\%) en "lae inkomstegroep" $(27,1 \%)$ as die twee grootste subgroepe. Die sogenaamde "armstes van die armes" is slegs in 8,3\% van die gevalle geteiken. Die middel-inkomstegroep het net beperkte aandag ontvang $(6,3 \%)$, terwyl geen pertinente dienste aan die hoër inkomstegroep gelewer is nie.

Die feit dat dienslewering op die arm gedeelte van die bevolking gefokus was, kan as positief beskou word. Dit het nie alleenlik beleidsvereistes nagekom nie, maar moet ook gesien word in die lig van die groot plaaslike armoedevraagstuk. So byvoorbeeld word 50\% van Suid-Afrikaanse huishoudings as arm geklassifiseer (May, 1999:53) en is 32,8\% van die Noordwes Provinsie se potensieel ekonomiese bevolking werkloos (SAIR, 1998:249). Tog is dit kommerwekkend dat geen gemeenskapswerkdienste aan die hoë inkomstegroep gelewer word nie. Hierdie groep ervaar ook probleme soos substansmisbruik en MIV/VIGS. Praktisyns moet gevolglik daarteen waak om vanweë Suid-Afrika se groot armoedevraagstuk, nie sekere dienste totaal na te laat nie.

\section{DIAGRAM 6 \\ DIE GEOGRAFIESE VERSPREIDING VAN DIE TEIKENGEMEENSKAPPE}

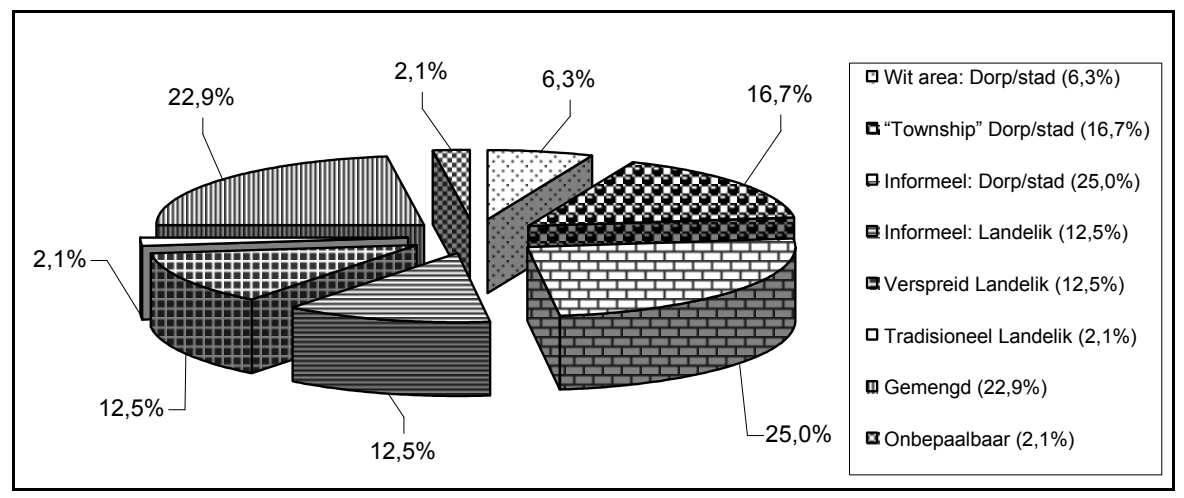

\section{Die geografiese verspreiding van teikengemeenskappe}

Daar is, benewens die kenmerke van die kliëntsisteme self, ook in die ondersoek op hul geografiese ligging gelet. Die data wat in hierdie verband ingewin is, word in Diagram 6 vervat.

Diagram 6 toon aan dat $48,0 \%$ van die projekte in stedelike en dorpsgebiede geloods is, terwyl slegs $27,1 \%$ van die landelike gebiede spesifiek geteiken het. Hierdie data moet gesien word teen die agtergrond dat 65,2\% van die Noordwes Provinsie se bevolking landelik is (SAIR, 1998:105), dat 72\% van Suid-Afrika se arm populasie in landelike gebiede woon (May, 1999:54) en dat daar historiese agterstande in dienslewering aan landelike gebiede opgebou het (SA, 1997:14, 19; Southall, 1999:85; Van Aardt, 1994:129).

Dit is uit die voorafgaande duidelik dat gemeenskapswerkdienslewering in landelike gebiede nog gebrekkig is en dat die sogenaamde "stedelike voorkeur" (urban bias) steeds voortduur. Derhalwe is transformasie in hierdie verband nie net in die Noordwes Provinsie nodig nie, maar waarskynlik ook in die hele Suid-Afrika.

\section{GEVOLGTREKKINGS EN RIGLYNE}

Daar kon tot drie kategorieë van gevolgtrekkings vanuit die betrokke ondersoek gekom word. Dit raak onderskeidelik die gemeenskapswerkproses, praktykmodelle en beleidsvereistes. 
Die ondersoek het eerstens aangedui dat die implementering van gemeenskapswerkdienste wel oorwegend verloop volgens die proses soos in die teorie uiteengesit. Dit was egter opvallend dat praktisyns se benadering baie meer kwalitatief van aard was en dat min, indien enige, wetenskaplike instrumente in behoeftebepalings en evaluerings aangewend is. Dit dui daarop dat die wetenskaplike standaarde soos in die teorie voorgestel, nie altyd gehandhaaf is nie.

Ten opsigte van die praktykmodelle het dit geblyk dat die voorligtingsmodel oorbenut en van die ander modelle onderbenut is. Die keuse van gemeenskapsvoorligting kan moontlik aan Suid-Afrika se groot behoefte aan gemeenskapsopvoedingsdienste (Weyers, 1991:143) toegeskryf word, maar ook aan die feit dat dié benadering groot getalle mense met relatief min insette bereik. Die resultaat is egter dat dienste neig om nie aan beleidsvereistes te voldoen nie. Hiervoor is die groter benutting van die gemeenskapsontwikkelingsmodel 'n noodsaaklikheid.

Rakende die mate waarin dienslewering aan beleidsvereistes voldoen het, kon daar tot veral twee baie pertinente gevolgtrekkings gekom word. Dit was eerstens duidelik dat dienslewering wel getransformeer het in terme van veral die ras, kwesbaarheid en finansiële posisie van kliëntsisteme wat geteiken is. Tog was dit tweedens duidelik dat dit nog steeds nie ten volle aan hetsy die beleidsvereistes of die aard van Suid-Afrika se ontwikkelingsproblematiek beantwoord het nie. In hierdie verband behoort veral die volgende terreine en kliëntsisteme in die toekoms meer aandag te ontvang:

- die algemene ekonomiese ontwikkeling van gemeenskappe en veral die implementering van inkomstegenererende projekte en werksverwante programme (bv. beskermde werkswinkels);

- die bevrediging van verál benadeelde groepe se basiese behoeftes (behuising, voeding, 'n inkomste, water, ens);

- dienslewering aan straatkinders;

- dienste aan die jeug wat veral sal fokus op die ontwikkeling van hul ouerskapsvaardighede, die voorkoming van misdaad en die generering van 'n eie inkomste;

- die daarstelling van voedingsprogramme, dag- en tuisversorging en kort-inblysentrums, tesame met die opleiding en ondersteuning van die versorgers van bejaardes en ander kwesbares;

- dienste wat die misbruik van en geweld teen vroue aanspreek;

- gesinsprogramme wat sal fokus op huweliksvoorbereiding, ouerskapsvaardighede en die hantering van gesinsgeweld;

- meer gemeenskapsgebaseerde programme wat die integrasie van fisies- en geestesgestremdes, substansafhanklikes, vorige oortreders en persone met chroniese siektes (insluitend MIV/VIGS) in die gemeenskap sal bevorder (dit sluit die skep van dag- of tuisversorging, mobiele klinieke en tydelike skuilings in);

- die mobilisering van ondersteuningsgroepe vir persone met spesiale behoeftes (bv. substansafhanklikes en MIV/VIGS geïnfekteerdes/geaffekteerdes); en

- 'n baie groter klem op dienslewering in landelike gebiede.

Die navorsingsbevindinge het verskeie implikasies vir die lewering van gemeenskapswerkdienste in die Noordwes Provinsie, asook vir Suid-Afrika as geheel. Hierdie implikasies is tot die volgende ses riglyne vir toekomstige optrede omvorm.

1. Duidelikheid moet verkry word oor wat gemeenskapswerk- en gemeenskapsontwikkelingsdienste op grondvlak werklik behels. 
- Die praktiese operasionalisering van die betrokke twee konsepte kan die vorm van 'n algemeen aanvaarde tipologie van projekte aanneem.

- Die ontwikkeling van so 'n tipologie behoort die gesamentlike taak van praktisyns, die owerheidsektor en akademici te wees.

- In die ontwikkeling van die tipologie kan daar onder andere gebruik gemaak word van die klassifikasie-raamwerk wat vir die onderhawige ondersoek ontwikkel is.

2. Praktisyns moet tydens die gemeenskapswerkproses meer van kwantitatiewe meetinstrumente gebruik maak. Dit geld veral by behoefte-/probleembepalings en by evaluering.

3. Gemeenskapswerkdienste moet beter gekoördineer word.

- In dié verband behoort die daarstelling van "sentrale gemeenskapswerkprojek-registers" waaraan beide die openbare en private sektor deelnemers is, vir gebiede oorweeg te word.

- Die stigting van "forums" waar praktisyns sake van gemeenskaplike belang kan bespreek, moet oorweeg word.

4. Daar behoort ' $n$ beter passing te wees tussen die behoeftes en probleme wat spesifieke gemeenskappe ervaar, die beleidsvereistes en die tipe praktykmodel wat benut word. In hierdie verband behoort daar veral op die volgende gelet te word:

- Handelinge wat daarop gerig is om selfhelp by gemeenskappe te bevorder, moet meer sentraal tot dienslewering staan.

- Die ontwikkeling en herverspreiding van hulpbronne is 'n beleidsvereiste. Gevolglik behoort die benutting van die maatskaplike beplanningsmodel meer in dienslewering voor te kom, al is dit soms net ter sekondêre ondersteuning van ander modelle.

- Praktisyns sal in 'n groter mate buite die eng welsynsterrein moet begin beweeg en via multidissiplinêre samewerking dienste op die gemeenskapsontwikkelingsterrein begin lewer.

5. Daar is bevind dat praktisyns wel oor die vermoë beskik om met kundiges oor die verskillende sektore heen saam te werk. Hierdie multi-sektorale samewerking en die wedersydse benutting van mekaar se kundigheid behoort egter meer uitgebreid voor te kom.

6. Daar bestaan bepaalde leemtes in die terreine en kliëntsisteme wat tans in die Noordwes Provinsie in dienslewering geteiken word. Dieselfde tendense kom waarskynlik ook in ander provinsies voor. Dit maak dit noodsaaklik dat beter provinsiale en nasionale statistiek oor bestaande dienste gehou sal moet word, dat die wetenskaplike identifisering en prioritisering van streeks- en veral plaaslike behoeftes as 'n gesamentlike taak van die openbare en private sektor beskou sal word en dat daar beter samewerking tussen veral provinsiale maatskaplike ontwikkelingsdepartemente en private welsynsorganisasies sal wees.

Ten spyte van al die leemtes wat met behulp van die ondersoek geïdentifiseer is, het dit tog een belangrike, globale bevinding opgelewer. Dit is naamlik dat maatskaplike werkers in die praktyk reeds ontsaglik baie in terme van gemeenskapswerkdienste vermag het. Dit spreek uit die groot getalle persone wat bereik is, die diversiteit van kliëntsisteme wat gehelp is, die dikwels moeilike ontwikkelingsterreine wat betree is en die variasie van praktykmodelle wat benut is. Dit was veral duidelik dat die gemeenskapswerkdienste van die private welsynsektor in die betrokke provinsie, en waarskynlik ook in die hele Suid-Afrika, reeds goed gevestig is. 


\section{BIBLIOGRAFIE}

ANC 1994. Implementing the RDP. [Web:] http://www.polity.org.za/govdocs/rdp/rdp6.html [Date of access: 8 July 2000].

ANC 1997. The core values of the RDP. [Web:] http://www.anc.org.za/ancdocs/discussion/ rdp.html [Date of access: 8 July 2000].

ARCHES, J.L. 1999. Challenges and dilemmas in community development. Journal of Community Practice, 6(4):37-53.

BARNARD, P.W. 1989. Rural community development: an operational model. Port Elizabeth: University of Port Elizabeth. (D.Phil thesis)

BOND, P 1997. Ditching the poor?: the municipal infrastructure framework. South African Labour Bulletin, 21(2):19-22.

BROWN, H. \& PARTAB, R. see FERGUSON BROWN, H. \& PARTAB, R.

CLARKE, L. 1992. Reaping what has been sown: the social and environmental cost of the neglect of the rural areas. In: VERLOREN VAN THEMAAT CENTRE, (ed) South Africa in transition: urban and rural perspectives on squatting and informal settlement in environmental context. Pretoria: University of South Africa, 86-93.

COETZEE, J.K. \& GRAAFF, J. 1996. Reconstruction, development and people. Johannesburg: Thomson Publishing (Pty) Ltd.

DEPARTMENT OF SOCIAL DEVELOPMENT see SOUTH AFRICA (Rep). Department of Social Development.

DEPARTMENT OF WELFARE see SOUTH AFRICA (Rep). Department of Welfare.

FERGUSON BROWN, H. \& PARTAB, R. 1999. Social work in the new South Africa: which way for justice and development? Social Work/Maatskaplike Werk, 35(2):138-151.

FRANCIS, D. \& HENDERSON, P. 1992. Working with rural communities. London: The MacMillan Press.

GRAY, M. 1996. Towards an understanding of developmental social work. Social Work Practice, 96(1):9-13.

GRAY, M. 1997. A pragmatic approach to social development: part 2. Social Work/Maatskaplike Werk, 33(4):360-373.

GRAY, M. 1998. Welfare policy for reconstruction and development in South Africa. International Social Work, 41(1):23-37.

KEPE, T. 1999. The problem of defining community: challenges for the land reform programme in rural South Africa. Development Southern Africa, 16(3):415-433.

LOMBARD, A. 1991. Gemeenskapswerk in verhouding tot gemeenskaps- en maatskaplike aksie, gemeenskapsorganisasie, maatskaplike beplanning en gemeenskapsontwikkeling. In: LOMBARD, A.; WEYERS, M.L. \& SCHOEMAN, J.H. Gemeenskapswerk en gemeenskapsontwikkeling: perspektiewe op mensontwikkeling. Pretoria: HAUM. 
MANDELA, N. 1994b. Introduction to the reconstruction and development programme. [Web:] http://www.polity.org.za/govdocs/rdp/rdp.html [Date of access: 8 July 2000].

MAY, J. 1999. Poverty and inequality in South Africa. Indicator South Africa, 15(2):53-58.

MIDGLEY, J. 1995. Social development: the developmental perspective in social welfare. London: SAGE Publications. 194 p.

NAIDOO, J. 1995. Taking the RDP forward. s.l.: Office of the President.

NEUMAN, W.L. 1997. Social research methods: qualitative and quantitative approaches. Boston: Allyn and Bacon. 560 p.

POPPLE, K. 1995. Analysing community work: its theory and practice. Buckingham: Open University Press. $131 \mathrm{p}$.

ROTHMAN, J. 1995. Approaches to community intervention. In: ROTHMAN, J.; ERLICH, J.L. $\&$ TROPMAN, J.E. (eds) Strategies of community intervention. Itasca: F.E. Peacock Publishers.

SA see South Africa (Rep.)

SAIR (South African Institute of Race Relations) 1995. Race Relations Survey 1994/95. Johannesburg: SAIR.

SAIR (South African Institute of Race Relations) 1998. South Africa Survey 1997/98. Johannesburg: SAIR.

SCHOEMAN, J.H. 1980. Die gemeenskapswerkproses. In: HUGO, E.A.K.; SCHOEMAN, J.H. \& ENGELBRECHT, J.F.P. Gemeenskapswerk. Pretoria: Heer.

SINGH, A. 1999. Women and empowerment through the economy of affection in KwaZulu-Natal: its significance for sustainable development. Development Southern Africa, 16(3):467-488.

SOUTH AFRICA (Rep). Department of Social Development 2001. Community work projects 2001. Available: http://www.welfare.gov.za/Documents/2002/Stats/stats/com.PDF [Date of access: 5 October 2002].

SOUTH AFRICA (Rep). Department of Social Development 2002. Strategic Plan 2002/03 2004/05, March 8 2002. Available: http://www.socdev.gov.za/documents/2002/March/splan [Date of access: 19 Aug. 2002].

SOUTH AFRICA (Rep). Department of Welfare 1997. White Paper for Social Welfare. Pretoria: Government Printer.

SOUTH AFRICA (Rep). Department of Welfare 1998. Social Welfare Action Plan, April 1998. [Web:] http://www.welfare.gov.za/documents/doc1998/SWAP [Date of access: 19 Aug. 2002].

SOUTH AFRICA (Rep). Department of Welfare 1999. Financing policy. (Notice 463, 1999). Government Gazette, 1988:405.

SOUTHALL, H. 1999. Inequity and resource allocation in South Africa: the case of Development Region D. Journal of Contemporary African Studies, 11(1):85-103.

STAPLES, L.H. 1999. Community oriented primary care and macro social work practice. Journal of Community Practice, 6(1):61-69.

SWANEPOEL, H. 1997. Community development: putting plans into action. (3rd ed) Kenwyn: Juta. 
SWANEPOEL, H. \& DE BEER, F. 1994. Guide for trainee community development workers. Halfway House: Southern Book Publishers (Pty) Ltd.

TAYLOR, G.J. 1994. Community participation in development projects: a sociological study. Port Elizabeth: University of Port Elizabeth. (MA thesis)

VAN AARDT, C. 1994. The future South Africa: issues, options and prospects. Pretoria: J.L. van Schaik.

VAN DEN BERG, A.M. 2002. Riglyne vir die lewering van gemeenskapswerkdienste deur die formele welsynsektor. Potchefstroom: PU vir CHO. (MA tesis)

VAN EEDEN, E.S.; RYKE, E.H. \& DE NECKER, I.C.M. 2000. The welfare function of the South African government before and after apartheid. Social Work/Maatskaplike Werk, 36(1):124.

WEYERS, M.L. 1991. Praktykmodelle en strategieë in gemeenskapswerk. In: LOMBARD, A, WEYERS, M.L. \& SCHOEMAN, J.H. Gemeenskapswerk en gemeenskapsontwikkeling: perspektiewe op mensontwikkeling. Pretoria: HAUM.

WEYERS, M.L. 1997. Nuwe lig op gemeenskapswerk en -ontwikkeling: 'n werkboek. Potchefstroom: Keurkopie.

WEYERS, M.L. 1999. Community education in the new millennium. Paper presented at the Biannual Congress of the Development Society of Southern Africa (DSSA) held in Johannesburg, South Africa.

WEYERS, M.L. 2001. The theory and practice of community work: a South African perspective. Potchefstroom: Keurkopie.

Mev AM van den Berg, 'n maatskaplike werker in diens van NG Welsyn, Krugersdorp, Suid-Afrika.

Prof ML Weyers, Skool vir Psigo-Sosiale Gedragswetenskappe: Vakgroep Maatskaplike Werk, Noordwes-Universiteit (Potchefstroomkampus), Suid-Afrika. 